\title{
Designing a MOOC - A new channel for teacher professional development?
}

\author{
Jean-François Van de Poël $1^{1 / 2}$ and Dominique Verpoorten ${ }^{1 \text { https://orcid.org/0000-0002-5604-4833 }}$ \\ ${ }^{1}$ IFRES, Traverse des Architectes, B63b, University of Liège (Belgium) \\ ${ }^{2}$ CSE, Amphipôle 200-2, University of Lausanne (Switzerland)
}

\begin{abstract}
This paper investigates the pedagogical benefits that 17 lecturers involved in the design of a MOOC reported in a questionnaire survey. Results reveal a fair amount of gains for several teaching skills and a strong appreciation of the collective training approach practiced during the 9-month MOOCs production process. These findings are of interest to staff development units, technology-enhanced learning competent bodies, and researchers concerned with collective modalities for scholarship of teaching and learning.
\end{abstract}

Keywords: MOOCs, faculty development, SoTL, P.E.P.I.T.E. methodology, quality teaching criteria, Chickering and Gamson principles, Margaryan principles, Merrill principles

\section{Introduction}

\subsection{Teachers as MOOC consumers}

A university MOOC policy can serve various purposes: raising international exposure, contributing to universal access to knowledge, yielding new profits, researching learning behaviors in large data sets, fostering staff pedagogical development. As for the latter outcome, teacher training literature has recently included MOOC development in its realm. However, its major concern bears on MOOCs as delivery instruments for teachers' initial or in-service training. MOOCs would open new avenues to teach large numbers of instructors (Castaño-Muñoz, Kalz, Kreijns, \& Punie, 2018; Koutsodimou \& Jimoyiannis, 2015; Jobe, Östlund, \& Svensson, 2014). Marquis (2013) sees in MOOCs a solution to fix two major hurdles inherent in training: cost and time. In the same vein, Bali (2013) enumerates 5 teaching benefits which should encourage teachers to be formed by the means of MOOCs. To this list, Rivera and Ramirez (2015) add the development of digital skills. In 2015, Dikke and Faltin locate, on various platforms, 130 MOOCs likely to train teachers' professional competences. A study of Ho et al. (2015) finds that, among 200.000 respondents to a survey of reasons to take MIT MOOCs, 39 percent self-identified as a past or present teacher. Surveys of 11 MITx courses on edX (Seaton, Coleman, Daries, \& Chuang, 2014) found that one in four respondent identified as past or present teachers. Laurillard (2016) transposes the model of MOOC consumption to the huge amount of teachers it 
would be necessary to form with regard to the needs of South countries in education: "If we are to achieve the UNESCO Sustainable Development Goal (http://uis.unesco.org) of universal basic education, we need tens of millions of as-yet untrained teachers to educate school-age children. MOOCs cannot directly teach those children, but they can train non-professional adults to become those teachers. Such a "large-scale cascade model" of online learning would support the development of a much larger teaching workforce". On top of the works mentioned above, Misra (2018) adds a reflection on the institutional actions one should undertake to push MOOCs with determination as instruments of teacher development.

\subsection{Teachers as MOOC producers}

Compared to the "consumption" of MOOCs in the context of teacher training, articles dealing with the "production" of MOOCs as pedagogical development opportunities for the holders of these MOOCs remain a modicum. Docq and Hamonic (2015) question the effects of MOOC design with 3 assumed added-values of blended learning: the cultivation of a student-centered approach, the modernization of the university and teachers' professionalization. The article suggests that part of the benefit for professional development would flow from the insertion of lecturers in a training community of colleagues facing similar challenges at the same time. In a convergent and rather convoluted case study, Bartoletti (2016) observes the development and the deployment of a MOOC. In conclusion, the author grants the whole process of a "reflective potential" (MOOC design as a "reflective laboratory", p. 8) stemming from an unusual level of pedagogical challenge combined with a "team-based MOOC design". Pedagogical development would be stimulated by interpersonal discussions conducive of (re-)examination in one's manner of teaching.

The relative scarcity of this second type of studies (MOOC design as a lever of pedagogical development for the lecturers-designers) might logically be explained by the limited number of involved teachers and by a certain difficulty to access the field and the subjects. This is the reason why IFRES, the staff development team for the University of Liège, has decided to document the effects of the support it has given to the holders of two MOOC cohorts. The research questions guiding this local qualitative research are:

- Do the efforts of the support team to use the MOOC production process as an incentive for professional development materialize in "feeling of learning" on the side of teachers (research question tackled by questionnaire 1)?

- To what extent do lecturers consider to have improved specific instructional skills and thanks to which element of the MOOC production process (research question tackled by questionnaire 2)?

- Are lecturers able to ascertain the pedagogical quality of their MOOC and is their opinion confirmed by professional educationalists (research question tackled by questionnaire 3)? 


\section{Methodology}

\subsection{Participants}

In 2016, the vice-chancellor of the University of Liège (Belgium) launched a pilot project for MOOC production. Due to the success of the three first instances, the program was extended with a second group of MOOCs. The 17 respondents to the survey are all lecturers committed to a MOOC of the first or second season (https://www.funmooc.fr/universities/universite-de-liege).

\subsection{MOOC production process}

To give an adequate account of the declared effects of the MOOC design process on pedagogical development, one must describe the training approach adopted throughout the project. This approach is closely coupled with the MOOC production methodology gradually defined at Uni. Liège. Labelled with the acronym P.E.P.I.T.E. (Fig. 1, left side), each letter refers to a stage development of the MOOC:

- Preparation: lecturers outline their MOOC syllabus, taking into account existing MOOCs to avoid duplications and stipulating the audiences they plan to address.

- Elaboration: lecturers write the scripts and story-boards of the video sequences and record them.

- Production: lecturers monitor the video editing and fix the additional digital inlays. They also design appropriate learning activities.

- Implementation: lecturers upload contents on online platform (France Université Numérique, https://www.fun-mooc.fr).

- Transmission: lecturers assist the participants during the MOOC deployment.

- Evaluation: lecturers send certificates and analyze the MOOC run in order to regulate its next iteration.
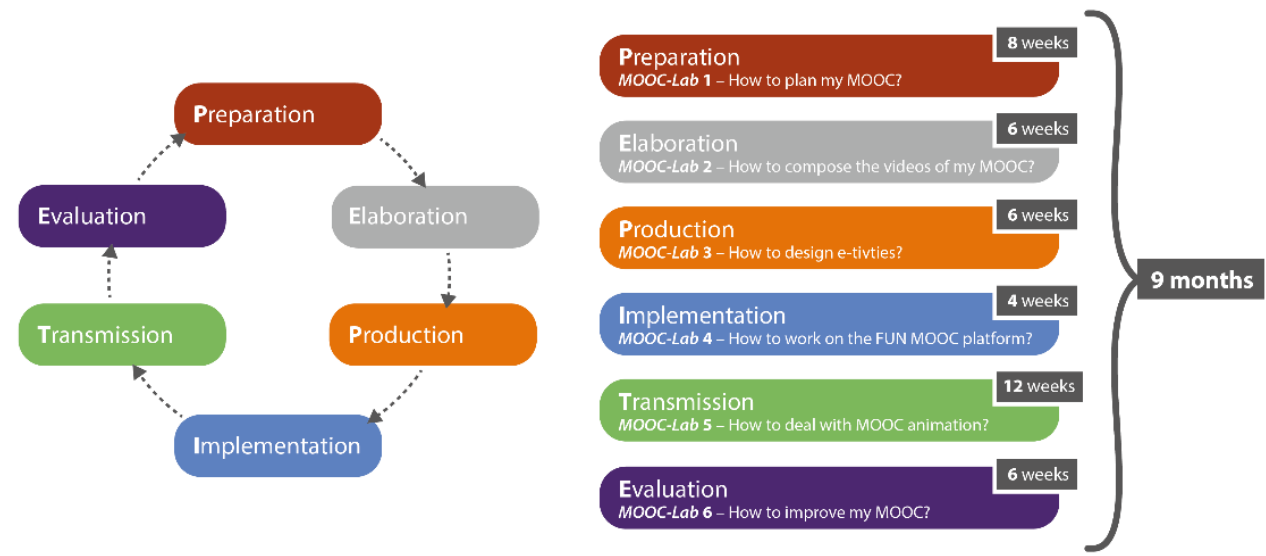

Fig. 1. Each stage of the P.E.P.I.T.E. MOOC production methodology (left side) is closely coupled with a staff development workshop ("MOOC-Lab", right side). 
To each of these stages, a MOOC-Lab, i.e. a 3-hour training session, is carefully harnessed (Fig. 1, right side). Between MOOC-Labs, the support team meets personally the MOOC holders to secure progress. An articulation is thus created between collective workshops, individual counseling sessions, and personal work. Attendance to MOOC-Labs is one of the conditions for being granted the funding for the MOOC. A recurring component of the MOOC-Labs - and an expected purveyor of pedagogical development - is a table (Fig. 2) condensing and contrasting 4 lists of principles for quality teaching: Chickering and Gamson (1987), Merrill (2002), the complement to Merrill by Margaryan, Bianco, and Littlejohn (2015), and Hew (2016)

\begin{tabular}{|c|c|c|c|}
\hline $\begin{array}{l}\text { CHICKERING \& GAMSON (1987) - } \\
\text { Good teaching... }\end{array}$ & $\begin{array}{l}\text { MERRILL (2002) - Learning is } \\
\text { promoted when... }\end{array}$ & $\begin{array}{l}\text { MARGARYAN ET AL. (2015) - } \\
\text { Learning is promoted when... }\end{array}$ & $\begin{array}{l}\text { HEW (2014) - Factors } \\
\text { participants perceive as engaging }\end{array}$ \\
\hline $\begin{array}{l}1 \ldots \text { develops reciprocity and } \\
\text { cooperation among students }\end{array}$ & & $\begin{array}{l}\text {... learners collaborate with } \\
\text { others. }\end{array}$ & Peer interaction \\
\hline ... encourages active learning & $\begin{array}{l}2 \ldots \text { new knowledge is applied by } \\
\text { the learner. }\end{array}$ & & Active learning \\
\hline ... gives prompt feedback & & $\begin{array}{l}3 \text { 3... learners are given expert } \\
\text { feedback on their performance. }\end{array}$ & \\
\hline $\begin{array}{l}\text {... respects diverse talents and } \\
\text { ways of learning }\end{array}$ & & $\begin{array}{l}4 . . . \text { different learners are } \\
\text { provided with different } \\
\text { avenues of learning, according } \\
\text { to their need. }\end{array}$ & \\
\hline \multirow[t]{2}{*}{$\begin{array}{l}\text {... encourages contact between } \\
\text { students and faculty }\end{array}$} & & & $\begin{array}{l}5 \text { Instructor accessibility and } \\
\text { passion }\end{array}$ \\
\hline & $\begin{array}{l}6 \text {... learners are engaged in } \\
\text { solving real-world problems. }\end{array}$ & & $\begin{array}{l}\text { Problem-centric learning with } \\
\text { clear expositions }\end{array}$ \\
\hline $\begin{array}{l}\text {... emphasizes time on task / ... } \\
\text { communicates high expectations }\end{array}$ & $\begin{array}{l}7 \text {...existing knowledge is activated } \\
\text { as a foundation for new } \\
\text { knowledge } \\
8 \text {... new knowledge is } \\
\text { demonstrated to the learner } \\
9 . . . \text { new knowledge is integrated } \\
\text { into the learner's world. }\end{array}$ & $\begin{array}{l}10 \text {...learners contribute to the } \\
\text { collective knowledge } \\
11 \text {...learning resources are } \\
\text { drawn from real-world } \\
\text { settings. }\end{array}$ & Using helpful course resources \\
\hline
\end{tabular}

Fig. 2. Four quality criteria grids form the connecting thread of the MOOC-Labs series of workshops. (For colored boxes and numbers, see section 3.3)

\subsection{Instruments and treatments}

To collect impressions of lecturers on their commitment to pedagogy, 3 ad hoc questionnaires (Appendix 1) have been designed.

Questionnaire 1. Made of open questions, it collects spontaneous perceptions of progress in pedagogy. The treatment of answers is done in light of a well fitted model regarding technology-enhanced learning: TPACK (Koelher \& Mishra, 2009; Loisy, Van de Poël, \& Verpoorten, 2017)

Questionnaire 2. It shapes for the lecturers a reflective moment around teaching skills enhanced by their participation to MOOC design. The treatment is made in light of the IFRES local framework of competencies ("CREER" model, Verpoorten et al. 2015) structuring all staff training and support actions at Uni. Liège: competency 1: to design consistent teaching sequences / competency 2: to implement the designed sequence (resources, tools, technologies...) / competency 3: to teach/guide/support learning processes / competency 4: to assess learning and to give feed-back / competency 5: to monitor the quality of the sequence through reflective practice.

Questionnaire 3. It targets lecturers' perceptions of the pedagogical quality they achieved in their MOOC. These perceptions were expressed through 11 pedagogical 
quality criteria lecturers were regularly exposed to during the MOOC-Labs (Fig. 2, in orange and numbered). After their taking position for each criterion (binary choice: "applied" versus "non-applied"), faculties justified why they thought this criterion was met or not. Non justified answers were excluded. When there were several lecturers attached to a single MOOC, the criterion was considered as met when one lecturer justified it correctly. In an attempt to restrain purely subjective viewpoints, lecturers' decisions on each criterion were confronted to the aggregated score of 3 pedagogical advisors who made the same evaluation exercise on each MOOC.

\subsection{Procedure}

The 3 questionnaires were filled in by 17 lecturers at the end of the final MOOC-Lab, in the workshop venue.

\section{Results}

\subsection{Spontaneous self-reported benefits (questionnaire 1)}

The 17 respondents stated together 26 distinct benefits coded in 4 categories (Fig. 3). Two of them can easily be labelled with TPACK framework for teacher knowledge for technology integration: "Technological knowledge" and "Pedagogical knowledge". Answers also contain frequent allusions to benefits in terms of collaboration with colleagues.

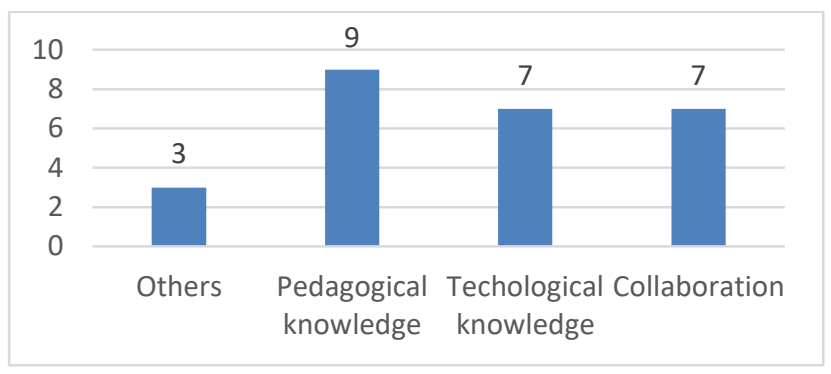

Fig. 3. Collaboration appears as an unexpected area of benefits for MOOC holders.

\subsection{Perception of progress in teaching skills (questionnaire 2)}

When asked to rate their progress onto the 5 skills of the CREER framework, the dominant feeling is one of progress (Fig 4). Lecturers grant a mode of 4 (I improved this competence a lot) to skill $\mathrm{n}^{\circ} 2$ (ability to implement a new learning sequence) and a mode of 2 (I improved this competence a bit) to skill $\mathrm{n}^{\circ} 4$, related to assessment of learning (Gherib, Dujardin, \& Verpoorten, 2016). Other skills are rated at a mode of 3 (I fairly improved this competence).

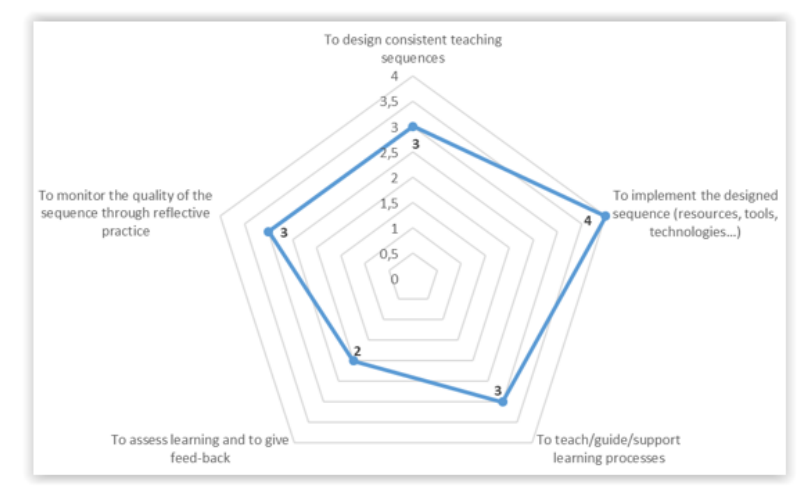


Fig. 4. All pedagogical skills are reported by lecturers to have been strengthened.

Lecturers consider that they have already transferred variegated pedagogical concerns and skills (Fig. 5) developed in the MOOC context to regular face-to-face course practice. The most frequent transfer concerns the key pedagogical notion of constructive alignment (Biggs, 1995) / triple consistency (Tyler, 1949; Martone \& Sireci, 2009; Castaigne, Petit, \& Verpoorten, 2007).

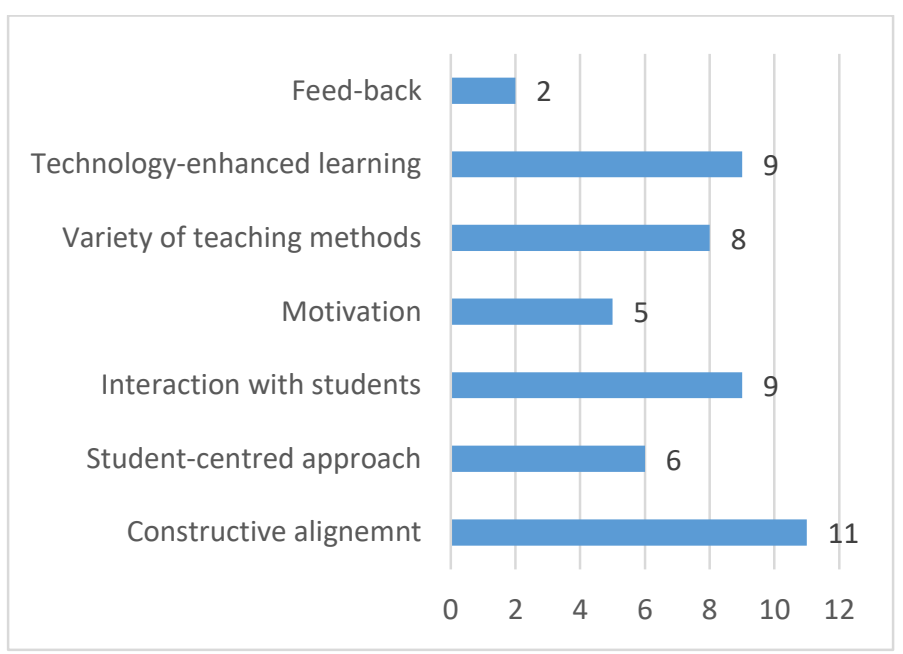

Fig. 5. Lecturers suggest that pedagogical skills and concerns sharpened in the MOOC context have diffused in other teaching activities ( 7 areas of transfer mentioned).

These self-reported gains have been achieved via different channels (Fig. 6). The intense, close, and individual work with pedagogical counselors is considered as the main catalyst of professional development.

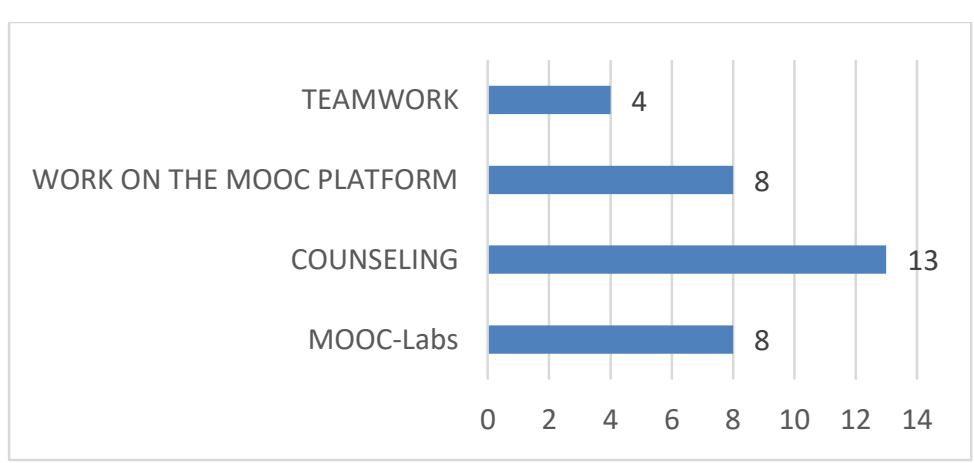

Fig. 6 Several components of the MOOC production process concur to skills development. 


\subsection{Quality teaching principles criteria (questionnaire 3)}

When asked about which criteria of quality teaching (Fig 2) they instantiated in their MOOC, 10 lecturers (committed to 5 MOOCs) are prone to report many of them (Fig. 7) and are able to give a pedagogical rationale as for this application.

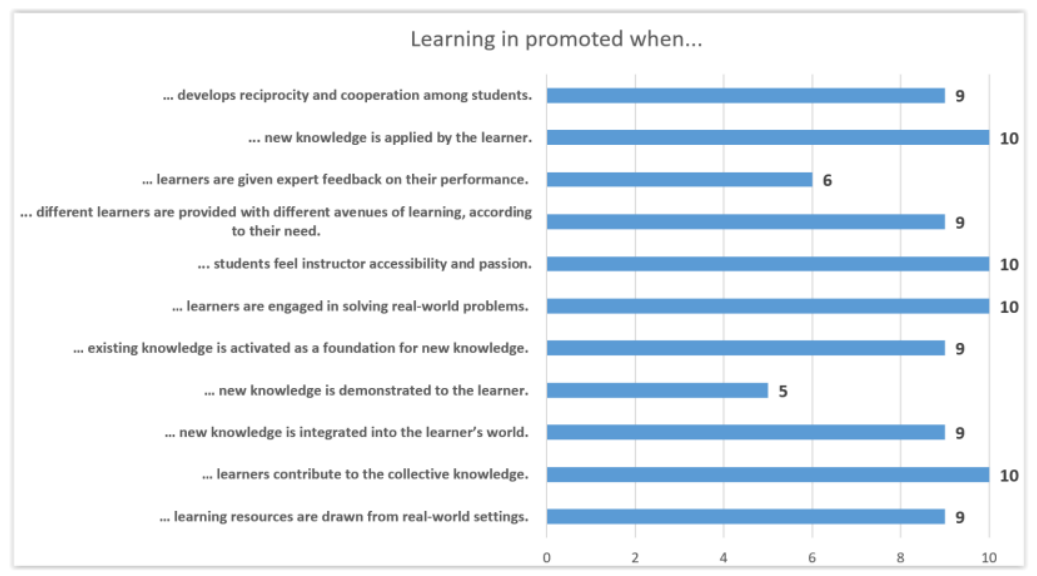

Fig. 7. MOOC-Labs regularly exposed lecturers to quality teaching principles (Fig. 2) and lecturers think most of these principles manifest in their MOOC.

When crosschecked with the agglomerate score of 3 pedagogical advisors, the level of agreement is high. Professionals are even more positive than the MOOC holders themselves (Fig. 8) about the operationalization of some pedagogical principles.

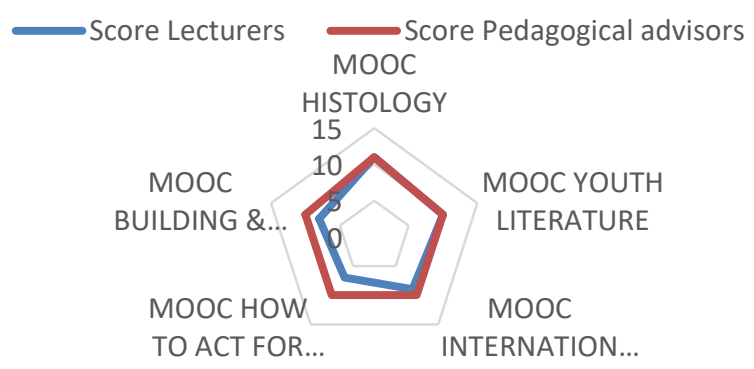

Fig. 8. The cumulated scores on quality teaching principles set by lecturers and pedagogical advisors for 5 MOOCs are rather similar and high in both cases.

\section{$4 \quad$ Discussion and limitations}

Can the production of a MOOC be reasonably used as an incentive for professional development? Data give convergent indications that, at least, being involved in such a 
process prompts feeling of learning on the side of teachers. Perceived benefits related to technical development (Fig. 3) seem natural, as the creation of a MOOC entails taking charge of new eLearning tools. The claims of pedagogical gains (Fig. 3) were less expected, all the more so that several experienced teachers were among the respondents. (Spontaneous self-reported learning benefits of Fig. 2 receive an indirect confirmation from Fig 7, 8, when teachers are asked to match pedagogical principles they covered in the MOOC-Labs to concrete realizations in their MOOCs).

Although collaboration is neither a dimension of the TPACK model of professional development (coding scheme of questionnaire 1) nor of the quality teaching principles (coding scheme of questionnaire 3), it consistently emerges, from teachers' answers, as a prime field of progress and a complementary channel of pedagogical development (Fig. 3, 6). In two seasons of MOOCs production, the support team has been struck by a major tendency of lecturers to develop MOOCs in teams, which was not demanded at the start. Indeed, the huge piece of work that a MOOC represents might explain a first move towards pooling people. It can also be seen as the trigger for a collective challenge and an opportunity for joint work. SoTL literature has recently called for more attention to collective modalities of teacher professional development (Verpoorten et al. 2017). The results presented here suggest that MOOCs convey this new kind of opportunity, as already put forward by Alony, Kaye, and Lambert (2015) or Najafi, Rolheiser, Harrison, and Håklev (2015).

Can the production of a MOOC reasonably be put in the service of a local teaching competency framework? According to the teachers, the answer is positive (Fig. 4). Mastery of the design, implementation, animation, and regulation of a teaching sequence is said to have improved throughout the 9-month process. Furthermore, these improved skills are claimed to have been transferred in face-to-face teaching contexts (Fig. 5). The vectors of this progress are manifold (Fig. 6): formal (MOOC-Labs) and tailored counseling moments, autonomous work on the platform, and team-based learning. The various elements of a MOOC development process might be mutually reinforcing and the challenging output that a MOOC embodies might act as an unexpected immersion of the lecturers into a motivating project-based pedagogy. To a certain degree of isomorphism, the quality teaching principles lecturers are encouraged to ingrain in their MOOCs also imbue the pedagogical support they receive.

As for further work, the descriptive data on teacher development provided here could favorably expand into a fine-tuned and differentiated understanding of how teachers understand MOOC design and interpret instructional design principles, beyond a rough yes/no implementation (Fig. 7) and in another time than at the end of the process when relief and satisfaction are likely to color answers.

Regarding limitations, relationships between lecturers and pedagogical advisors have developed during the 9 months of the MOOC production. Social desirability or, more to the point here, kindness to the support team, can be a shortcoming of the questionnaires. Similarly, the 3 pedagogical advisors who scored the MOOCs in the same way lecturers did (Fig. 8) are not foreign to the MOOC development process. Although inter-subjectivity was used to curb risks of self-indulgence, a review of the MOOCs quality by an independent instance would yield safer results. 


\section{References}

Alony, I., Kaye, S. \& Lambert, S. (2015, October). MOOCs' contribution to staff development and capacity building: Australian University Case study. Paper presented at the 26th ICDE World Conference, Sun City, South Africa.

Bali, M. (2013, July 12). 5 reasons teachers should dip into MOOCs for professional development. MOOC News and Reviews.

Bartoletti, R. (2016). Learning through design: MOOC development as a method for exploring teaching methods. Current Issues in Emerging eLearning, 3(1), 2.

Biggs, J. (1995). Enhancing teaching through constructive alignment. Higher Education, 32(3), 347-364.

Castaigne, J-L, Petit, L., \& Verpoorten, D. (2007). Introducing teachers and instructional developers to learning objects Four suggested shifts in prevailing discourse. In A. Targamadze (Ed.), Proceedings of the Advanced Learning Technologies and Applications conference (ALTA'2007) (pp. 73-79). Kaunas, Lithuania, Technical University Kaunas. http://hdl.handle.net/2268/152053

Castaño-Muñoz, J., Kalz, M., Kreijns, K., \& Punie, Y. (2018). Who is taking MOOCs for teachers' professional development on the use of ICT? A cross-sectional study from Spain. Technology, Pedagogy and Education, 27(5), 607-624.

Chickering, A., \& Gamson, Z. (1987). Seven principles for good practice in undergraduate education. AAHE bulletin, 3, 7.

Dikke, D., \& Faltin, N. (2015, July). Go-Lab MOOC - An online course for teacher professional development in the field of Inquiry-based science education. Paper presented at the 7th Conference on Education and New Learning Technologies, Barcelona, Spain.

Docq, F., \& Hamonic, E. (2015, May). Why make MOOCs? Effects on on-campus teaching and learning. Paper presented at the Conference EMOOCs 2015, Mons, Belgium.

Gherib, C., Dujardin, J.-M., \& Verpoorten, D. (2016). MOOCs in business administration An overview of assessment practice. Proceedings of the Conference of the European Association for Practitioner Research on Improving Learning (EAPRIL) 2015, Issue 2 (pp. 258-268). Leuven, Belgium: EAPRIL Office. http://hdl.handle.net/2268/194562

Hew, K. (2016). Promoting engagement in online courses: what strategies can we learn from three highly rated MOOCs. British Journal of Educational Technology, 47(2), 320-341.

Ho, A. D., Chuang, I., Reich, J., Coleman, C., Whitehill, J., Northcutt, C., Williams, J., Hansen, J., Lopez, G., \& Petersen, R. (2015). HarvardX and MITx: Two years of open online courses. HarvardX Working Paper No. 10.

Jobe, W., Östlund, C. \& Svensson, L. (2014). MOOCs for Professional Teacher Development. In M. Searson \& M. Ochoa (Eds.), Proceedings of SITE 2014--Society for Information Technology \& Teacher Education International Conference (pp. 1580-1586). Jacksonville, Florida: AACE.

Koelher, M., \& Mishra, P. (2006) Technological Pedagogical Content Knowledge: A Framework for Teacher knowledge. Teacher College Record, 108(6), 1017-1054.

Koutsodimou, K., \& Jimoyiannis, A. (2015, November). MOOCS for teacher professional development: Investigating views and perceptions of the participants. Paper presented at the 8th International Conference of Education, Research and Innovation, Sevilla, Espana.

Marquis, J. (2013, May 21). Why MOOCs are good for teacher professional development! OnlineUniversities.com.

Misra, K. (2018). MOOCs for Teacher Professional Development: Reflections and Suggested Actions. Open Praxis, 10(1), 67-77. 
Laurillard, D. (2016). The educational problem that MOOCs could solve: professional development for teachers of disadvantaged students. Research in Learning Technology, 24.

Loisy, C., Van de Poël, J.-F., \& Verpoorten, D. (2017). Regards croisés sur deux dispositifs de formation techno-pédagogique, leur outillage conceptuel et l'évaluation de leurs bénéfices. In P. Detroz, M. Crahay, A. Fagnant (dir.), L'évaluation à la lumière des contextes et des disciplines (p. 277-307). Louvain-la-Neuve, Belgique : De Boeck. http://hdl.handle.net/2268/205471

Margaryan, A., Bianco, M. \& Littlejohn, A. (2015). Instructional quality of Massive Open Online Courses (MOOCs). Computers \& Education, 80, 77-83.

Martone, A., \& Sireci, S. (2009). Evaluating Alignment between Curriculum, Assessment, and Instruction. Review of Educational Research, 79(4), 1332-1361.

Merrill, M. (2002). First principles of instruction. Educational technology research and development, 50(3), 43-59.

Najafi, H., Rolheiser, C., Harrison, L., \& Håklev, S. (2015). University of Toronto instructors' experiences with developing MOOCs. The International Review of Research in Open and Distributed Learning, 16(3).

Rivera N., \& Ramírez M. (2015, November). Digital skills development: MOOCs as a tool for teacher training. Paper presented at the 8th International Conference of Education, Research and Innovation, Sevilla, Espana.

Seaton, D., Coleman, C., Daries, J., \& Chuang, I. (2014, February 8). Teacher Enrollment in MITx MOOCs: Are We Educating Educators? Educause Review.

Tyler, R. W. (1949). Basic principles of curriculum and instruction. Chicago: Universi-ty of Chicago Press.

Verpoorten, D., Jérôme, F., Delfosse, C., \& Detroz, P. (2015, October). Infusing SoTL components in staff training - A faculty development continuum at the university of Liège. Paper presented at the 12th annual conference of the International Society for the Scholarship of Teaching and Learning (ISSOTL) - Leading learning and the scholarship of change, Melbourne, Australia. http://hdl.handle.net/2268/187394

Verpoorten, D, Leduc, L., Mohr, A., Marichal, E, Duchâteau, D, \& Detroz, P. (2017). "Feedback First year - A critical review of the strengths and shortcomings of a collective pedagogical project”. In J. Friberg \& K. McKinney (Eds.), Applying the Scholarship of Teaching and Learning Beyond the Individual Classroom Level. Bloomington, USA: Indiana University Press. http://hdl.handle.net/2268/206782

\section{Appendix 1}

Questionnaire 1 aimed at collecting spontaneous ideas on progress as teachers, with 2 open questions: 1) as a teacher, what do you get out of your participation in the MOOC project?, 2) What are you proud of in your MOOC and what could you improve? Questionnaire 2 aimed to connect lecturers' experience as MOOC producers to the university teaching competencies reference framework. Questions were aligned with the 5 skills of the model CREER: do you consider that your experience of MOOC design has not/a bit/fairly/strongly developed competency 1, 2, 3, 4, 5. (Fig. 4). To complement these suggested skills, teachers were asked if/what they had already transferred from MOOCs to other courses. Lastly, lecturers were asked which component of the MOOC project contributed the most to the progress they claim. Questionnaire 3 focused on 11 quality teaching principles, asking teachers to inspect for each of them if it was materialized in their MOOC and how (Fig. 7). Three pedagogical advisors did the same for the sake of a comparison with teachers' answers (Fig. 8). 